\title{
Critical Skills for Infrastructure Procurement: Insights from Developing Country Contexts
}

DOI:

10.1108/JEDT-08-2021-0437

\section{Document Version}

Accepted author manuscript

Link to publication record in Manchester Research Explorer

\section{Citation for published version (APA):}

Asiedu, R. O., Manu, P., Mahamadu, A. M., Booth, C., Olomolaiye, P., Agyekum, K., \& Abadi, M. (2021). Critical Skills for Infrastructure Procurement: Insights from Developing Country Contexts. Journal of Engineering, Design and Technology, [JEDT-08-2021-0437]. https://doi.org/10.1108/JEDT-08-2021-0437

\section{Published in:}

Journal of Engineering, Design and Technology

\section{Citing this paper}

Please note that where the full-text provided on Manchester Research Explorer is the Author Accepted Manuscript or Proof version this may differ from the final Published version. If citing, it is advised that you check and use the publisher's definitive version.

\section{General rights}

Copyright and moral rights for the publications made accessible in the Research Explorer are retained by the authors and/or other copyright owners and it is a condition of accessing publications that users recognise and abide by the legal requirements associated with these rights.

\section{Takedown policy}

If you believe that this document breaches copyright please refer to the University of Manchester's Takedown Procedures [http://man.ac.uk/04Y6Bo] or contact uml.scholarlycommunications@manchester.ac.uk providing relevant details, so we can investigate your claim.

\section{OPEN ACCESS}




\section{Journal of Engineering, Design and Technology \\ DOI: 10.1108/JEDT-08-2021-0437}

\section{CRITICAL SKILLS FOR INFRASTRUCTURE PROCUREMENT: INSIGHTS FROM DEVELOPING COUNTRY CONTEXTS}

Richard Ohene Asiedu ${ }^{1}$, Patrick Manu ${ }^{2}$, Abdul-Majeed Mahamadu ${ }^{3}$, Colin Booth ${ }^{3}$, Paul Olomolaiye $^{4}$, Kofi Agyekum ${ }^{5}$, and Mohamed Abadi ${ }^{2}$

${ }^{1}$ Department of Building Technology, Koforidua Technical University, Koforidua, Ghana.

${ }^{2}$ Department of Mechanical, Aerospace and Civil Engineering, The University of Manchester, Manchester, United Kingdom.

${ }^{3}$ Department of Architecture and the Built Environment, University of the West of England, Bristol, United Kingdom.

${ }^{4}$ Vice-Chancellor's Office, University of the West of England, Bristol, United Kingdom.

${ }^{5}$ Department of Construction Technology and Management, Kwame Nkrumah University of Science and Technology, Kumasi, Ghana

${ }^{*}$ Corresponding author

Email: Patrick.Manu@manchester.ac.uk

Telephone: 00441613067572

\section{Acknowledgements}

Appreciation is extended to the United Kingdom Department for International Development (DfID) for providing funding for data collection in Nigeria as part of the Urbanisation Research Nigeria programme. 


\begin{abstract}
Purpose: Effective procurement of infrastructure is partly dependent on infrastructure procurement personnel having the skills that are important for the discharge of their role. Addressing the infrastructure deficits in developing countries, therefore, calls for an understanding of the skills that are important for the discharge of the roles of public personnel that are involved in infrastructure procurement. This study investigates these skills from the perspective of public infrastructure procurement personnel in the sub-Saharan African region.
\end{abstract}

Design/methodology/approach: A questionnaire survey of procurement personnel yielded 590 useable responses, which were analysed using t-tests and exploratory factor analysis (EFA).

Findings: EFA established eight key components of important infrastructure procurement skills to include skills related to: project success factors; social and environmental sustainability; marketing and e-procurement; project phase management, the application of procurement laws and procedures; soft skills, ICT and communication; and data analysis and team building.

Originality/value: The findings are crucial in developing infrastructure procurement capacity building programmes that would be appropriate for infrastructure procurement personnel in developing country contexts. Infrastructure procurement personnel ought to engage more in capacity development training that is aligned to enhancing skills within the eight components.

Keywords: Developing countries, infrastructure, procurement, skills, survey.

\title{
1.0 Introduction
}

Infrastructure refers to "a system of basic physical structures, facilities and services that are provided to address energy demand, water and food shortages, unemployment, poverty and general improvement in the quality of life" (Asuquo et al., 2021, p. 1-2). Governments worldwide are responsible for the provision of infrastructure (Dithebe et al., 2019; Asuquo et al., 2021). As an important element of modern society, infrastructure is considered as the backbone of various economic activities (Organisation for Economic Cooperation and Development (OECD), 2015). This implies that the absence of a functional infrastructure system can significantly impact the economy of every country. Currently, this assertion has been confirmed by Asuquo et al. (2021) who iterated that in developing countries, the provision of infrastructure projects is central to economic development. Most governments (both developing and developed) across the globe invest a large share of their resources into infrastructure development such as schools, hospitals, roads, railway, power, and telecommunication (Manu et al., 2021). This is besides the fact that these infrastructure are key drivers towards the attainment of the United Nation's Sustainable Development Goals (SDGs). This intervention is yielding the expected outcomes in most countries across the world (United Nations Economic and Social Council, 2016).

The Global Construction Perspectives and Oxford Economics (2013) predicts a 70 percent rise in global construction output by the year 2025. While deliberate investment contributions are made to bridge the infrastructure gap between low and 
high-income economies, the expectation is that a larger proportion of the expected infrastructure growth would be realized in developing and emerging economies (Mahamadu et al., 2018). Public procurement is an important conduit for delivering public infrastructure. Public procurement comprises of all activities beginning with planning and forecasting, identification of needs, sourcing, and solicitation of offers, evaluation of offers, review, and award of contracts, contracting and all phases of contract administration until delivery of the goods, the end of a contract, or the useful life of an asset (United Nations Office for Project Services, 2010). For any organisation to function effectively, it is important to re-emphasise the need for essential competencies and skills for managing these organisational functions. Several authors have investigated the challenges confronting procurement organisations within the public service (Araujo et al., 2005; Ameyaw et al., 2012; Amemba et al., 2013). The findings of most of the investigations highlight procurement personnel capacity challenges (World Bank, 2013). The existence of a functionally robust procurement system, therefore, depends to a large extent, on the availability of a competent team equipped with the requisite skills and knowledge for any specific procurement activities (Thai, 2008).

The lack of capacity and knowledge to steer procurement processes has resulted in poor project governance with ramifications on project cost, time, and quality (Asiedu et al., 2016). Cost and time overruns and poor project quality have the potential to negatively impact project viability and reduce the volume of infrastructure that can be realised from a given funding amount. Humpherson (2011) describes procurement skill as the ability to interact on equal and professional terms with contractual counterparties in the procurement and management of programmes and projects. Skills may be imparted or trained and have a multi-layered concept extending through education, training, learning, practice, educational attainment, and involvement (Elias and McKnight, 2001; Esposto, 2008), directed by code of ethics and conduct. Skill is complex and dynamic and therefore necessitates consistent updates to keep up with current technological trends and market revolution for organizational competitiveness and productivity (Tassabehji and Moorhouse, 2008).

In the Sub-Saharan Africa (e.g., Nigeria and Ghana), a deficit in the quantity and quality of infrastructure is reported (Mahamadu et al., 2018). This deficit is partly attributed to the procurement of such countries which are riddled with an array of challenges, typical of which is the lack of requisite skills of the public procuring entities of such nations (World Bank, 2013). Though an important issue that merits attention, research conducted in this area is scanty. For instance, Mahamadu et al. (2018) conducted a study into ascertaining the infrastructure procurement skills gap amongst procurement personnel in Nigeria's public sector. The findings from their study revealed that out of the 45 procurement skills areas operationalised, there existed significant gaps in 38 of them. Among the key areas that exhibited such gaps were computing/ICT, problem solving, communication, decision making, and health and safety. Though their study is significant, it only concentrated on identifying the gaps that exist among procurement personnel with not emphasis laid on the critical skills needed by these professionals to bridge the skills gap. In an alternative study in Ghana, a strong link was drawn between the reliance on untrained procurement staff and the misapplication of the procurement procedures which affects infrastructure procurement activities (Addo-Duah et al., 2014). Furthermore, in Ghana, a study has shown that attention has been given to the formulation of a legal and regulatory framework and anti-corruption measures to secure economic transparency and accountability to the detriment of developing the skills of procurement professionals 
(Addo-Duah et al., 2014). Effective procurement of infrastructure is partly dependent on infrastructure procurement personnel having the skills that are important for the discharge of their role. Addressing the infrastructure deficits in developing countries, therefore, calls for an understanding of the skills that are important for the discharge of the roles of public personnel that are involved in infrastructure procurement. This study, therefore, sought to provide this insight from the perspective of public infrastructure procurement personnel in developing countries (i.e., Ghana and Nigeria). The next section of this paper discusses the status of infrastructure and the skills gap of procurement personnel in developing countries. Subsequently, the research methodology, findings, discussion, and concluding remarks are presented.

\subsection{Literature Review}

\subsection{Status of infrastructure in developing countries}

The literature on the role of infrastructure to output, productivity and welfare abound (e.g. Asuquo et al., 2021). A substantial portion of the empirical studies on the effects of infrastructure has focused on its long-run contribution to the level or growth rate of aggregate income or productivity. Most of the studies conducted reveal a positive longrun effect of infrastructure on output, productivity, or growth rate (e.g. Bivens, 2017). Other studies have examined the effects of infrastructure on income inequality (e.g Calderón and Servén, 2014). The rationale according to the African Development Report (2015) is that infrastructure provision may have an uneven effect on the income and welfare of the poor by raising the value of the assets they hold (such as land or human capital), or by lowering the transaction costs (e.g. transport and logistic costs) they incur to access the markets for their inputs and outputs (see Bivens, 2017). Other related studies have also examined poverty effects of specific infrastructure projects using matching techniques that combine samples of beneficiaries with samples drawn from regular household surveys (e.g. Gebregziabher et al., 2009; Yasuyuki, 2015).

Notwithstanding, infrastructure deficit remains a worldwide phenomenon although its effects are greatly felt in developing countries ( Holtz and Heitzig, 2021). Comparatively, the African continent remains at the forefront of infrastructure development needs. Challenges confronting infrastructure in developing countries differ according to the type of country with the most fragile states faced with impossibilities while resource-rich countries lag despite their wealth. Indeed, nowhere is the dearth of infrastructure more critical than Sub-Saharan Africa. The huge gap manifest in the form of congested and deteriorated roads, the absence of recreational facilities, unstable power supply, and lack of or poor public infrastructure assets (UNECF, 2008).

Infrastructure development accounts for more than fifty percent of Africa's value-added growth performance with the possibility of contributing more to the future. Countries in the region trail their counterparts in other developing countries almost by every measure of infrastructure coverage (World Bank Group, 2017). For instance, countries in Africa were at par with their counterparts in South and East Asia with regards to their stocks in roads in the 1960s, telecommunication in the 1970s, and power generation in the 1980s (Foster and Briceño-Garmendia, 2009). Additionally, the power generating capacity in Sub-Saharan Africa was three times more than South Asia in 1970 (ibid). By the year 2000, the tables had turned with South Asia producing twice as much power per million people. Likewise, Sub-Saharan Africa had two times 
more telecommunication lines as South Asia in 1970, but by the year 2000, the two regions were at par. The challenging nature of Africa's economic geography poses a difficulty for the region's quest for infrastructure development. The continent is characterised by a relatively low population density, low rates of urbanization, and a high number of landlocked countries with several small economies (ibid).

A greater share of infrastructure projects in developing countries is publicly procured with the main driver for investment being the central government budget. The infrastructure deficit in developing countries, especially in Sub-Saharan Africa, implies the need for governments in the region to invest heavily in infrastructure procurement. This makes the effectiveness of public procurement and consequently the capacity of procurement personnel paramount.

\subsection{Critical skills requirement among procurement officials}

The rapid increase in the extent of procurement requirements and activities demands procurement personnel with the requisite skills and knowledge regarding contemporary technologies for managing procurement. Tassabehji and Moorhouse (2008) have identified a correlation between individual skills and organisational performance. According to the authors, while technical skills are seen as a predictor of firm performance, skills which consider non-behavioural skills such as communication and time management predict strategic purchasing while behavioural skills (soft skills) predict supplier responsiveness. Tremblay and Boyle (2018)also opines that irrespective of the robustness and availability of procurement laws, its effective implementation largely depends on the competencies of the workforce. In a study by Cousins et al. (2006), it was established that purchasers who have rather high level of skills tend to have more impact on financial and operational performance. Hence, the central issues therefore regarding the procurement capacity of individuals relate to the availability of the required competencies towards the management of procurement.

There have been several attempts to enhance the skill set of procurement professions within the public sector (Addo-Duah et al., 2014), although according to Giunipero and Pearcy (2000) there is currently no central reference point for the required procurement skills to allow for uniform capacity development. Nonetheless, Cousins et al. (2006) highlight the relevance of procurement skills and its effects on organisational performance and further recommends more generic management skills and improvement of procurement specific skills. Furthermore, several procurement capacity areas have been suggested to address the evolving roles of procurement to meet strategic objectives. Schapper et al. (2006) differentiated between the traditional and contemporary roles of procurement as indicated in Table 1.

\section{[Insert Table 1 approximately here]}

As a result of the changing roles in procurement, the required skills according to Tassabehji and Moorhouse (2008) are gradually becoming multidimensional that spans across interpersonal, strategic, technical, and managerial skills. Additionally, contemporary procurement requires expertise related to value derivation, total life 
cycle analysis, and application of information and communication technology ( AddoDuah et al., 2014). The extant literature offers several skills which are required for modern procurement (see Table 2). In line with Tassabehji and Moorhouse (2008), the skills, shown in Table 2, span across interpersonal, strategic, technical, and managerial skills.

[Insert Table 2 approximately here]

\subsection{Research Methodology}

This study adopted a positivist deductive research paradigm using a quantitative (survey) research strategy for investigating the important skills required by procurement personnel for infrastructure delivery in developing countries. The quantitative approach was selected over the qualitative strategy due to its suitability for capturing and exploring relationships between factors and for ascertaining a generic view of a phenomenon being studied (Yin, 2009; Creswell, 2009). Additionally, other researchers (e.g. Basheka, 2010, Addo-Duah et al., 2014, Mahamadu et al., 2018; Manu et al., 2018, 2019; Agyekum et al., 2021) have also adopted the survey strategy to investigate procurement capacity issues. According to Fellows and Liu (2008), the qualitative approaches are best suited for investigating subjective reality which runs at variance with the aim of this study. The adoption of the quantitative survey approach, therefore, ensured that the experience and views of the procurement personnel were adequately captured.

\subsection{Survey Design}

The survey focused on practitioners involved in infrastructure procurement within the public sector in Ghana, and those within the local government authorities and state government agencies in Nigeria. . Ghana is made up of sixteen regions and operates a single unified procurement act. Nigeria on the other hand has 36 states and a Federal Capital Territory. Majority of these states operate different procurement laws except for federal government projects (Manu et al., 2017). Although the two countries operate parallel procurement acts, evidence in the literature suggests that issues of procurement relating to Ghana are similar to the situation in many African countries (e.g., Nigeria) and some Asian countries (Ameyaw et al., 2012). In addition to this, the skills needed for any procurement activity (see Table 1) are generic, hence, one may expect that procurement professionals, despite the laws they are operating with, within the two countries under investigation would need similar skills.

A questionnaire was administered to the procurement personnel. The questionnaire covered the background information of the respondents and an assessment of the importance of a list of procurement skills for the procurement of infrastructure. The first section of the questionnaire captured data on: the respondents' role; education; the number of years worked within their current role; the number of years worked as an infrastructure procurement personnel; the type of infrastructure respondents are involved in their procurement; and the phase of infrastructure procurement respondents are involved in. The second section of the questionnaire captured data on the respondents' perception regarding the importance of a list of procurement skills to the discharge of their role in the procurement of infrastructure. Forty five (45) 
procurement skills obtained from the literature (Table 2) were assessed. The respondents were asked to rate the extent to which they agreed that the skills are important for the discharge of their role on a five-point Likert scale (i.e. $5=$ strongly agree; 4 = agree; 3 = neutral; 2 = disagree and 1 = strongly disagree) .

Prior to distribution of the questionnaire, ethics approval was provided by the relevant university faculty ethics review committee. As an ethics requirement a participant information sheet was included with the questionnaire and informed consent was also sought from respondents.

To ensure the achievement of adequate responses amidst the unreliable nature of obtaining responses via a postal survey in Ghana and Nigeria, in both countries, the questionnaires were administered by hand delivery and collection to procurement personnel in public agencies. The sample frame was made up of personnel involved in procuring infrastructure in public institutions in the two countries. Procurement personnel within the Ashanti, Greater Accra and Easter Regions were contacted in Ghana because of the geopolitical significance of the regions (Manu et al., 2021). In Nigeria, the professionals contacted were within the Kaduna and Oyo states. It is acknowledged that Lagos and Abuja have more Federal Government Agencies involved in procurement activities than Kaduna and Oyo states combined. However, government reports have identified Kaduna and Oyo states to be key locations in Nigeria, with serious infrastructure shortfalls (Oyo State Government, 2010; Kaduna State Government, 2018)). As a result, the professionals within those states were well placed to provide the research with the needed information for the study. The purposive sampling approach was used to locate the respondents. . Table 3 shows a summary of questionnaires distributed in each country and their respective response rate. In all, 853 questionnaires were administered comprising $480(56 \%)$ in Ghana and $373(43 \%)$ in Nigeria. Out of this, a total of 590 useable questionnaires (i.e. $69.17 \%$ ) were retrieved in Ghana $(n=302$; response rate $=62.92 \%)$ and Nigeria $(n=288$; response rate $=77.21 \%$ )

[Insert Table 3 approximately here]

\subsection{Data analyses}

Data from the questionnaire were coded and inputted into Statistical Software for Social Science (SPSS) version 23 for analysis. The analyses were conducted using statistical techniques such as descriptive statistics (i.e. mean, standard deviation, and frequency) and inferential statistics. The inferential statistical analyses comprised: one-sample t-test to identify the most important/critical infrastructure procurement skills; independent samples t-test to explore associations between important procurement skills and procurement role and endeavours (i.e. type of infrastructure in which personnel is involved in their procurement, and the phase of infrastructure procurement involvement by personnel), and exploratory factor analysis to extract the underlying components of the most important/critical infrastructure procurement skills. Regarding the one-sample t-test, a test value of 3.5 (which approximates to the scale point of 4, meaning "agree" was used (see Ahadzie et al., 2008; Mahamadu et al., 2018). Thus, if a skill obtains a mean score which is significantly greater than 3.5 ( $p$ $(1$-tailed $) \leq 0.05)$, then it implies that the procurement personnel generally agree that 
that skill is important for the procurement of infrastructure. The t-test was used because it helped in determining if there was a significant difference between the means of two groups (i.e., the professionals from Ghana and Nigeria), which may be related in certain features (i.e., procurement skills).

\subsection{Findings}

\subsection{Respondents' Background Information}

Table 4 shows the demographic information of the respondents. It shows that procurement officers constituted the majority of the respondents, followed by engineers, quantity surveyors, administrators, other roles, purchasing officers, architects, estate surveyors, builders, urban planners and land surveyors, in that sequence. The other roles comprised engineering technologists, accountants, geologists, hydrologists, and environmental health officers. The average years of experience of the respondents in their professional role is 9.12 (standard deviation =7.29). The average years of experience of the respondents in infrastructure procurement is 6.62 (standard deviation $=5.70$ ). The majority of the respondents are involved in the procurement of housing infrastructure, followed by education, transport, power, water and sanitation, and health infrastructure, in that sequence. The distribution of the phase of infrastructure procurement involvement by the respondents shows that the majority are involved in tendering/sourcing stage. This is followed by execution stage, initiation/planning stage, closure and review stage, and disposal stage. Overall, the demographic information shows that the respondents have adequate professional background and experience in the procurement of infrastructure and thus their responses regarding the second section of the questionnaire can be deemed credible.

\section{[Insert Table 4 approximately here]}

\subsection{Important Skills for Infrastructure Procurement - One Sample t-test}

The one-sample t-test (with test value $=3.5$ ) results of the important/critical skills needed for infrastructure procurement are shown in Table 5 . The test revealed that all the 45 skills examined are generally perceived to be important to the procurement of infrastructure. A ranking of the 45 skills based on mean scores revealed the topmost quarter include: communication (oral/written); procurement planning; quality management; project monitoring and auditing/evaluation; time management; leadership; value engineering; health and safety management; tendering; decision making; computing/ICT; and problem solving. The least important skills according to the respondents include: entrepreneurship; application of corporate social responsibility procedures; business case development; stress management; and cross cultural awareness. 
Exploratory factor analysis (EFA) was adopted to uncover the correlation amongst the procurement skill variables to find out which variables could be measuring aspects of the same phenomenon that were thought of as contributing to procurement competencies. It, therefore, presents the choice of gaining a clear interpretation of the variables by explaining the variance in the observed variables in terms of underlying latent factors. The EFA results are shown in Table 6. The Kaiser-Meyer-Olkin measure of sampling adequacy (i.e. 0.946), which is greater than the minimum criterion of 0.5 , confirms the suitability of the sample for factor analysis (Field, 2013). The Bartlett's Test of Sphericity being significant (Chi-Square $=10754.381(\mathrm{df}=946), p<0.001)$ also confirmed the suitability of factor analysis for the data (Field, 2013). Principal component analysis (being the method of extraction) and varimax rotation (being the method of rotation) were adopted for the factor analysis. Based on the eigenvalue of 1.0 and factor loading set at 0.5 , eight components were extracted. The variances explained by each of the components is as follows: Component $1=32.46 \%$; Component $2=5.21 \%$; Component $3=4.04 \%$; Component $4=3.64 \%$; Component 5 $=2.84 \%$; Component $6=2.80 \%$; Component $7=2.57 \%$; and Component $8=2.40 \%$. The total variance explained by the eight components is approximately $55.80 \%$. Based on an examination of the composing variables with the highest factor loadings, the components can be described as 1 = skills related to project success factors; 2 = skills related to social and environmental sustainability; 3 = skills related to marketing and e-procurement; 4 = skills related to project phase management; $5=$ skills related to the application of procurement laws and procedures; $6=$ soft skills; $7=$ ICT and communication skills; and 8 = Data analysis and team building skills.

[Insert Table 5 approximately here]

[Insert Table 6 approximately here]

\subsection{Discussion}

The study has revealed skills that are important for public personnel involved in infrastructure procurement within the Sub-Saharan African context. The extent of the importance of the skills for infrastructure procurement could vary depending on the procurement role, type of infrastructure procured, and the phase of infrastructure procurement involvement by procurement personnel. While all the 45 examined skills were deemed important by the procurement personnel for the discharge of their infrastructure procurement role, the study established that the important skills could condense into eight key components.

The major component comprises 7 variables (strategic planning, quality management, green procurement, risk management, relationship management, time management, and proposal evaluation). These 7 variables, which together explain $32.46 \%$ of the variability in the important competencies for infrastructure procurement by public personnel, were observed to describe "project success factors" (see Gunathilaka et al., 2013). Like any function, procurement supports many different kinds of projects. As a matter of fact, a competent procurement personnel must possess various skills 
to be able to engage with various stakeholders and suppliers in order to hit their mark. Key among these required skills as revealed in this study are strategic planning skills, quality management skills, green procurement skills, risk management skills, relationship management skills, time management skills, and proposal evaluation skills. These skills as revealed in this study are core project management skills. According to Bartolini (2014), project management is an inherent part of procurement; hence, solid project management skills must be able to assist procurement departments to build and maintain influence. This implies that attaching great importance to expanding the influence of procurement means having a strong belief in acquiring strong project management skills (Bartolini, 2014). According to Williams et al. (2018), the responsibilities of procurement professionals have changed from sheer buyers to managers of physical and intellectual assets, who require expertise in business skills, interpersonal skills, technical skills, transactional skills, strategic skills, and ethical leadership skills (Giunipero et al., 2006; Prier et al., 2010). These skills are required to ensure multifaceted project success. Conventionally, project success has been associated with adherence to cost, time, and scope. However, Shenhar and Dvir (2007) opine that project success can be deployed into more strategic dimensions such as project efficiency and planning. Meanwhile, the success of a project is largely affected by the standards that are set to assess the tenders. For example, several studies have discussed the significant challenges associated with the adoption of the least price as the only criteria for assessing the suitability of tenders (see Bruno et al., 2018; Doloi 2013; Witjes and Lozano, 2016) which highlights the important problem associated with the use of the lowest price as the sole evaluation criterion to reach sustainability goals (Agyekum et al., 2021). Including additional relevant criteria helps to ensure that the economic, technical, and professional capabilities of the tenderer meet the project and client goals. Besides, infrastructure procurement defines the global organisation and framework of tasks and authorities for personnel within the building process which is a crucial factor that leads to overall project success and client satisfaction. Saher and Khan (2018) have established that project risk has a substantial moderation effect on the correlation between strategic project planning and project success. A well-prepared project management plan, therefore, is positively influenced by institutional efficiency in organisations that include risk management and planning while implementing management practices. Hwang and $\mathrm{Ng}$ (2013) contend that one of the difficulties confronting the implementation of green procurement is the attendant challenges in selecting subcontractors that offer green construction services, associated with the insecurities and high cost of adopting green equipment and materials. Concerning buyer-supplier association, contractual relationship is portrayed as a continuum between arms-length contractual relations and obligational contractual relations. According to Rahmani et al. (2017), while relationship-based procurement suggests a major advantage to all project participants, decision-makers are cynical. This is attributed to the lack of robust concepts which makes it difficult to validate value for money for public projects, which may result in their dismissal in the future. According to Deep et al. (2018), the absence of an efficient supply chain risk management framework results in adversarial relationships which have the potential to pollute the project environment.

Secondly, the five variables; cross cultural awareness, stress management, application of corporate social responsibility procedures, environmental management, 
and health and safety management together describe skills related to "social and environmental sustainability". Public procurement organisations worldwide have designed sustainable public procurement (SPP) policies, which oblige suppliers to contribute to the attainment of policy objectives (Grandia and Voncken, 2019). The uptake and implementation of sustainable public procurement policies has received a growing attention in academia (Ongaro, 2017). The uptake and implementation of the SPP is reported to vary greatly across countries, organisations and projects (Grandia, 2016). This is because within public organisations, changes have to be made and barriers removed to achieve the SPP. Sustainable public procurement is considered an umbrella concept that encompasses concerns for social, economic and environmental aspects of procurement decisions (Grandia and Voncken, 2019). According to the Department of Health (2007), it is through the consideration of the balance of social, environmental, and economic factors that we recognise that what we purchase and how we purchase has such a significant role to play. Though the three dimensions must go together to achieve an inclusive and sustainable economic growth, of late the research community has paid attention to issues related to the social and environmental aspects of procurement (Gidigah et al., 2021). This is the case because firms that adhere to the Human-Centred Business Model (HCBM), which complies with a broad set of environmental and social sustainability principles seem perfectly suited already to meet the requirements and specifications of preferred and more specifically sustainable procurement policies (OECD, 2019). Within the context of this study, this assertion by OECD (2019) is the case because the findings revealed the social issues related to procurement to include cross cultural awareness, stress management, and application of corporate social responsibility procedures. The environmental issues were identified to include environmental management, and health and safety management. Sustainable procurement aligns with the principles of sustainable development which includes living within environmental limits (Zhao et al., 206). According to Bygeth and Hochschorn (2006), environmentally desirable procurement has been progressively growing in both public and private organisations in recent years. There is, therefore, the need for public institutions to appreciate and understand regulations and policies to manage the environmental impacts of their products (Committee for Environmental Cooperation, 1999). The advancement of corporate social responsibility has extended the forms of policies that are now frequently related to public procurement in mitigating environmental issues and social conditions. This according to Rimmington (2006) accounts for why issues about fair trade, reduction in child labour, and environmental sustainability have been brought to the forefront of public procurement discussions.

The four variables; marketing, e-procurement, research and development, and sustainable design collectively explain $4.04 \%$ of the variance in the important skills for infrastructure procurement. These four variables reveal the need for skills related to "marketing and e-procurement". Expectations to cross-train procurement officers in aspects of marketing, e-procurement, and sustainable design are increasing (Williams, 2018; Abdullahi et al., 2020). Modern procurement officers require expertise in marketing and e-procurement due to their management functions (Oke et al., 2018). According to Nkado (2000), the knowledge base of procurement professionals is key in meeting the changing demands and growth of their market share. Oke et al. (2018) suggest it is therefore required that quantity surveyors and allied procurement professionals within the built environment develop expertise in both curriculum and 
professional practice regulations to help sustain and win clients to ensure continuous existence. E-procurement is crucial in enhancing transparency, lowering administrative costs, and improving the economic outcome in a dynamic and competitive environment (Gascó, et al., 2018). The possible effect of public procurement on sustainability is obvious bearing in mind the size and impact of the infrastructure sector as a percentage of the GDP of a country (Preuss, 2009). However, the adoption of e-procurement is dependent on having adequate ICT/computing skills.

The four variables; tendering, project monitoring and auditing/evaluation, project scope definition, and project strategy development/organisational governance, explain $3.46 \%$ of the variance in the important skills for infrastructure procurement. The four variables describe skills related to key "project stage/phase management" along the lifecycle of an infrastructure project. Procurement outcomes in infrastructure projects are considered sensitive to decision making during the planning, design and execution phases of such projects. A procurement strategy will involve choices which are made to determine what must be delivered through a particular contract, the contracting arrangement, promotion of secondary procurement objectives among other things (Watermeyer, 2018). Procurement tactics will also involve the selection of the other party to a contract who is most likely to deliver best value or a cost-effective solution through the performance of the contract (Watermeyer, 2018). This means that for a procurement professional to be strategically and tactically sound, that person must possess certain key skills. The findings from this study revealed that a procurement professional must possess the appropriate tendering skills, project monitoring and evaluation skills, scope definition skills and organizational governance skills. These skills are crucial for managing various phases of projects. Public procurement practice, stretching from contractor selection to post-contract administrative evaluation, have become commonplace across the world as more governments attempt to reform their procurement function (Dimitri, 2013; Kaufmann et al., 2017). Past studies conducted in some advanced countries suggest that some tenderers find procurement regulations somewhat complex which tend to hinder innovation (Aschhoff and Sofka, 2009; Schapper et al., 2006). Choosing a competent contractor through an efficient tendering process is fundamental in ensuring successful project execution. Proper administration of procurement regulations and ethics ensures the tendering process runs smoothly. Sustainable infrastructure must develop technical and engineering skills as well as systems for data collection, monitoring, and evaluation. Monitoring and evaluation are crucial for the provision of a consolidated source of information that displays project progress and allows officials to learn from past experiences. However, according to Adjei-Bamfo and Maloreh-Nyamekye (2019), there is currently no formalised monitoring and evaluation systems in Ghana regarding sustainable public procurement while the needed personnel is lacking. This suggests the absence of the needed capacity to monitor activities of contractors to ensure compliance and guide procurement officials towards the administration of sustainability. The absence of proper monitoring and evaluation also results in opportunistic ventures (Adjei-Bamfo and Malori-Nyamekye, 2019).

Three variables; application of international procurement law and procedures, application of national procurement law and procedures, and application of modern integrated procurement procedures collectively describe skills related to the "application of procurement laws and procedures". Procurement has become a politically delicate issue especially because it constitutes a large share of public expenditure. Coupled with this is the extensive misinterpretations and ignorance 
among public officers regarding what procurement involves. The findings from this study have revealed that procurement professionals must develop skills in the application of international laws and procedures, application of natural procurement law and procedures, and application of modern integrated procurement procedures. There is often a lack of understanding regarding which skill is needed which poses a huge risk to good governance. Public procurement has ceased to be just a means to an end to being a policy tool that is used to realise expected outcomes. Outcomes that deliver wider public benefit demand assessment beyond financial metrics and require a longer-term measurement of impact (Grandia and Meehan, 2017). These measures may be new and inventive involving iterative network relationships between suppliers, service providers, public bodies, and communities. Hence, if public procurement lacks these capabilities, then its ability to reach desired outcomes in society is limited.

Additionally, the component "soft skills" clusters four variables; creative thinking, problem solving, entrepreneurship, and decision making. Soft skills are the skills required to have successful interactions with others (Lewis and Boucher, 2012). When accompanied by traditional technical skills, soft skills help to create a more wellrounded skills set. The right balance of soft and technical skills is critical to the success of any procurement department. They are those qualities that enable a person to interact, collaborate, and lead effectively. Soft skills are vital to any management position because they affect both external and internal relationships. According to Bag (2016), most of the procurement officers lack vital soft skills which are needed to complement the technical skills. However, as a procurement professional, especially, in a leadership position, one is expected to be able to effectively motivate the people who work for them, show leadership and bring out the best in employees (Fournier, 2020). From the findings of this study, it is evident that the respondents perceived creative thinking, problem solving, entrepreneurship and decision making to be critical soft skills required by procurement practitioners to be able to function appropriately. Literature reports on other equally important soft skills required by procurement professionals to include the ability to communicate with people at all levels of an organisation, liaise between departments, drive value into other areas of the business, and lead innovation and change (Lewis and Boucher, 2012; James, 2016; Fournier, 2020). It is expected that human resource managers will develop the required training manuals for procurement officers to enhance the essential soft skills. Relationship management/stakeholder engagement skills are very important so that candidates can engage with people and build rapport quickly. So too are supplier management skills and excellent negotiation skills (James, 2016). Soft skills help to enhance personal development and professional ethics. Decision making skills are considered amongst the most significant skills as it encapsulates skills such as flexibility, planning, and problem solving. Jordan and Bak (2016) hold the view that although problem solving skills, for instance, may be imparted in the classroom, professional experience is the most effective way of enhancing the skill.

Three variables; computing/ information communication and technology (ICT), communication (oral/ written), and conflict resolution and management were observed to collectively describe skills about "communication and use of ICT". Strong communication skills are necessary for procurement management. The wisdom of teams is hidden in the means of communication among professionals (Lewinson, 2010). Members of effective procurement teams cooperate with each other and clearly and consistently communicate with people within and outside the team regarding issues like vendor management and teamwork (Lewinson, 2010). Effective internal communications ensures that the right decisions are made, conflicts are constructively 
handled, and valuable feedbacks are received (Lewinson, 2010). In addition to the normal communication among team members, ICT is seen to play a significant role in innovation processes within the public sector while ICT driven innovations seem to depend on the general ICT infrastructure in a specific policy sector and/or in a particular country (Bekkers \& Homburg, 2007; Korteland \& Bekkers, 2008). Cooperation amongst project participants is enhanced through effective communication based on trust (Sarker et al. 1998), which is crucial to interface management (Shokri et al. 2012). Cross-functional communication helps to identify and track interface conflicts on time. When interface problems occur, effective and direct communication can help project participants analyse the causes and jointly seek solutions (Dettman and Bayer, 2012). Effective information flow, and relying on high communication quality between project stakeholders, can play a mediating role in the relationship.

Two variables; data (quantitative and qualitative) analysis and team building were observed to collectively explain skills related to "data analysis and team building". As the procurement team shifts from being a tactical function to strategic function within the supply chain, the skills required of procurement top performers shift as well. Data analysis and team building are two of such critical skills which the procurement team must possess at this stage. Data is a powerful and valuable tool for decision making when in the right hands; however, in the wrong hands it can be meaningless or even damaging to an organisation (ProcureAbility, 2020). As a procurement professional, one would be required to analyse large sets of data like category market data and internal historical procurement data. From this, such professionals are required to act as strategic advisors where they assist a business to develop category strategies, negotiation plans, and pricing models (ProcureAbility, 2020). According to Paulraj et al. (2006), assessing the effect of strategic procurement on supplier integration and performance demands an appreciation of the role procurement could play in integrating supplier-buyer relationships. On a construction project, procurement is responsible for purchasing design services, construction works, goods, etc. Performing this function goes with the formation of an effective procurement team. Team building thus, plays an important role in procurement in the construction sector. The procurement manager who leads the procurement team must possess special team building skills because of his broad roles in developing a clear procurement strategy for the purchasing of goods and services. Thus, skill types targeting global management, such as team building is becoming popular in relation to procurement specific skills.

\subsection{Conclusion and Recommendations}

Public procurement of infrastructure that is adequate and fit for purpose is partly contingent on the competencies of procurement personnel. The pressing need to bridge the growing infrastructure gap, therefore, requires an appreciation of the various skillset that is useful for procuring infrastructure. Developing countries, especially those in Sub-Saharan Africa remains deficient in both infrastructure (quality and quantity) and the right personnel within the various procurement entities. Literature is, however, unclear on the right mix of critical skills the various procurement personnel require to deliver the needed infrastructure effectively and efficiently. 
This study has investigated the important skills needed by public procurement personnel for the discharge of their role in terms of procurement of infrastructure. The study revealed 45 procurement skills that are important to public procurement personnel for the procurement of infrastructure. The study further established that these skills can be consolidated into eight key components of infrastructure procurement skills, namely: skills related to project success factors; skills related to social and environmental sustainability; skills related to marketing and e-procurement; skills related to project phase management; skills related to the application of procurement laws and procedures; soft skills; ICT and communication skills; and data analysis and team building skills.

The main implications of the study are two-fold:

(1) infrastructure procurement personnel should engage more in capacity development activities that are aligned to enhancing the skills that make up the eight key components of infrastructure procurement skills. In connection with this, the staff capacity building plans, programmes and initiatives of infrastructure procurement agencies also need to have greater alignment with the skills that make up the eight components;

(2) public infrastructure procurement agencies and relevant government agencies (e.g. public procurement governing authorities) in conjunction with other stakeholders (e.g. professional bodies, and educational institutions) need to offer a variety of skills development avenues/opportunities to enable procurement personnel to develop capacity within the key components of infrastructure procurement skill.

Though the findings of this study provide some useful inferences, key limitations are acknowledged. To begin with, the study adopted a quantitative survey of procurement personnel from various public institutions in both Nigeria and Ghana. The underlying explanations regarding the effects of the observed skills on the attainment of procurement objectives could, therefore, not be explored deeper. Qualitative studies could be conducted in the future to unearth further empirical realities regarding the critical skills identified. Also, taking into consideration the fact that the two countries operate parallel procurement acts, it would be good for future studies to consider how the acts of the individual countries impact the critical skills required for infrastructure procurement in the two countries. Again, it must be noted that though Ghana has 16 regions that operate a unified procurement act, Nigeria has 36 states and a Federal Capital Territory with each state having their own procurement laws slightly different from the national public procurement act operated in Nigeria. This implies that though the critical skills identified could be generic, the extent of generalisability of the insights may be limited given that the data was obtained from procurement professionals within specific states and regions in Nigeria and Ghana, respectively. To assist in better generalization, future studies could consider the procurement professionals within other states in Nigeria as well as other developing countries.

\section{References}


Abdullahi, B., Ibrahim, Y.M., I brahim, A. and Bala, K. (2020), "Development of etendering evaluation system for Nigerian public sector", Journal of Engineering, Design and Technology, Vol. 18 No. 1, pp. 122-149.

Addo-Duah, P., Westcott, T., Mason, J., Booth, C. and Mahamadu, A. (2014), "Developing capability of public sector procurement in Ghana: An assessment of the road subsector client", Proceedings of Construction Research Congress 2014, American Society of Civil Engineers, Atlanta, GA, USA, 19-21 May.

Adjei-Bamfo, P., Maloreh-Nyamekye, T. and Ahenkan, A. (2019), "The role of egovernment in sustainable public procurement in developing countries: A systematic literature review", Resources, Conservation and Recycling, Vol.142, pp. 189-203.

African Development Report (2015), Growth, poverty and inequality nexus:

Overcoming barriers to sustainable development, available at:

https://www.afdb.org/fileadmin/uploads/afdb/Documents/Publications/ADR15 UK.pdf (accessed 28/09/2021).

Agyekum, K., Adinyira, E. and Amudjie, J. (2021), "Ethical misconducts within the invitation to tender and tender evaluation and award stages of construction contracts in Ghana", Journal of Engineering, Design and Technology, Vol. 19 No. 5, pp. 11011123.

Ahadzie, D.K., Proverbs, D.G. and Olomolaiye, P.O. (2008), "Critical success criteria for mass house building projects in developing countries", International Journal of Project Management, Vol. 26 No. 6, pp. 675-687.

Ahadzie, D.K., Proverbs, D.G., Olomolaiye, P.O. and Ankrah, N. (2009), "Towards developing competency-based measures for project managers in mass house building projects in developing countries", Construction Management and Economics, Vol. 27 No. 1, pp. 89-102.

Amemba, C. S., Nyaboke, P. G., Osoro, A. and Mburu, N. (2013), "Challenges affecting public procurement performance process in Kenya", International Journal of Research in Management, Vol. 3 No. 4, pp. 41-55.

Ameyaw, C., Mensah, S. and Osei-Tutu, E. (2012), "Public procurement in Ghana: the implementation challenges to the public procurement law 2003 (Act 663)", International Journal of Construction supply chain management, Vol. 2 No. 2, pp. 5565.

Appiah, R. E. (2011), "Building Relevant Skills for Public Procurement", EProcurement Bulletin, Vol. 2 No. 1, pp. 1-6.

Araujo, A., Carter, R. Y., Callender, G., Drabkin, D., Grimm, R., Jensen, K., ... and Telgen, J. (2005), "Challenges in public procurement: An international perspective", $K$. V. Thai (Ed.). Boca Raton, FL: PrAcademics Press, pp. 1-20.

Asiedu, R. O. and Alfen, H. W. (2016), "Understanding the underlying reasons behind time overruns of government building projects in Ghana", KSCE Journal of Civil Engineering, Vol. 20 No. 6, pp. 2103-2111. 
Aschhoff, B. and Sofka, W. (2009), "Innovation on demand - can public procurement drive market success of innovations?", Research Policy, Vol. 38 No. 8, pp. 1235-1247.

Asuquo, C., Lashinde, A. and Adu, E. (2021), "Governance quality and public sector procurement of infrastructure projects in developing countries: evidence from Nigeria", Journal of Public Procurement, ahead-of-print, DOI: 10.1108/JOPP-10-2019-0067.

Bag, S. (2016), "Modeling the soft skills of green procurement professionals using Interpretive Structural Modeling Approach", In book: Strategic Management of Sustainable Manufacturing Operations Edition: Advances in Logistics, Operations, and Management Science (ALOMS) Book Series, Chapter: 6 Publisher: IGl Global, Editors: Rameshwar Dubey, Angappa Gunasekaran, pp. 120-131.

Bartolini, A. (2014), Skills for the modern procurement pro-project management skills, available at: https://cporising.com/2014/06/19/skills-for-the-modernprocurement-pro-project-management-skills/ (accessed 26/09/2021)

Basheka, B.C. (2010), "Public procurement skills requirement framework for local government system in Uganda: perception from professionals", available at: www.ippu.or.ug (accessed 1 March 2016).

Bekkers, V. and Homburg, V. (2007), "The myths of e-government: Looking beyond the assumptions of a new and better government", The Information Society, Vol. 23 No. 5, pp. 373-382.

Bivens, J. (2017), The potential macro-economic benefits from increasing infrastructure investment. Economic Policy Institute, Washington DC, available at: https://files.epi.org/pdf/130111.pdf, (accessed 28/09/2021).

Bruno, T., Gelderman, C.J., Lambrechts, W. and Semeijn, J. (2018), "The promise of best value procurement: Governance and (in)stability of specifications within an innovative biogas project." Journal of Cleaner Production, Vol. 172, pp. 1465-1475.

Byggeth, S. and Hochschorner, E. (2006), "Handling trade-offs in Ecodesign tools for sustainable product development and procurement", Journal of Cleaner Production, Vol. 14 No. 15/16, pp. 1420-1430.

Calderón, C. and Servén, L. (2014), Infrastructure, growth, and inequality: an overview. The World Bank.

Calderón, C. and Servén, L. (2008), Infrastructure and economic development in subSaharan Africa, Development Research Group Macroeconomics and Growth Team, Policy Research Working Paper 4712. Washington, DC: World Bank.

Carr, A.S. and Smeltzer, L.R. (2000), "An empirical study of the relationships among purchasing skills and strategic purchasing, financial performance and supplier responsiveness", The Journal of Supply Chain Management, Vol. 36 No. 3, pp. 40-54.

Committee for Environmental Cooperation (1999), Supporting green markets, environmental labelling, certification and procurement schemes in Canada, Mexico, and the United States. Québec, Canada.

Cousins, P.D., Lawson, B. and Squire, B. (2006), "An empirical taxonomy of purchasing functions", International Journal of Operations and Production Management, Vol. 26 No. 7, pp. 775-794. 
Creswell, J.W. (2009), Research Design: Qualitative, Quantitative and Mixed Method Approaches, $3^{\text {rd }}$ ed., Sage, Thousand Oaks, California.

Dainty, A.R., Cheng, M.I. and Moore, D.R. (2004), "A competency-based performance model for construction project managers", Construction Management and Economics, Vol. 22 No. 8, pp. 877-886.

Deep, S., Gajendran, T., Jefferies, M. and Davis, P. (2018), "An analytical literature review of risks in collaborative procurement", In The Royal Institution of Chartered Surveyors-Annual Construction, Building and Real Estate Research Conference, London, UK. Available at: http://www. rics. org/Documents/COBRA (Vol. 202018) (accessed 5 August 2020).

Department of Health (2007), Procuring for Health and Sustainability 2012: Sustainable Procurement Action Plan. The Health and Social Care Sector Response to the Sustainable Procurement Task Force Report, Department of Health/NHS PASA, Reading.

Dettman, K. and Bayer, D. (2013), "Alignment partnering: A bridge to ADR processes?", Journal of Legal Affairs and Dispute Resolution in Engineering and Construction, Vol. 5 No. 2, pp. 60-66.

Dimitri, N. (2013), "Best value for money in procurement", Journal of Public Procurement, Vol. 13 No. 2, pp. 149-175.

Dithebe, K., Aigbavboa, C.O., Thwala, W.D. and Oke, A.E. (2019), "Analysis on the perceived occurrence of challenges delaying the delivery of water infrastructure assets in South Africa", Journal of Engineering, Design and Technology, Vol. 17 No. 3, pp. 564-571.

Doloi, H. (2013), "Empirical analysis of traditional contracting and relationship agreements for procuring partners in construction projects", Journal of Management in Engineering, Vol. 29 No. 3, pp. 224-235.

Elias, P. and McKnight, A. (2001), "Skill measurement in official statistics: recent developments in the UK and the rest of Europe", Oxford Economic papers, Vol. 53 No. 3, pp. 508-540.

Esposto, A. (2008), "Skill: An elusive and ambiguous concept in labour market studies", Australian Bulletin of Labour, Vol. 34 No. 1, pp. 100.

Fellows, R. and Liu, A. (2008), Research Methods for Construction, Blackwell Publishing, West Sussex.

Field, A. (2013), Discovering statistics using IBM SPSS Statistic, 4th ed., Sage Publications Ltd. Thousand Oaks, CA.

Foster, V. and Briceño-Garmendia, C. M. (Eds.). (2009), Africa's infrastructure: a time for transformation. The World Bank. 
Fournier, M. (2020), What skills are needed for a job in procurement? Available at: https://blog.procurify.com/2016/03/08/what-skills-are-needed-for-a-job-inprocurement/ (assessed 29/09/2021).

Gascó, M., Cucciniello, M., Nasi, G. and Yuan, Q. (2018), "Determinants and barriers of e-procurement: A European comparison of public sector experiences", Proceedings of the 51st Hawaii International Conference on System Sciences, pp. 2342-2351. DOI: 10.24251/HICSS.2018.294.

Gebregziabher, G., Namara, R. E. and Holden, S. (2009), "Poverty reduction with irrigation investment: An empirical case study from Tigray, Ethiopia", Agricultural water management, Vol. 96 No. 12, pp. 1837-1843.

Gidigah, B.K., Agyekum, K. and Baiden, B.K. (20210, "Defining social value in the public procurement process for works", Engineering, Construction and Architectural Management, ahead-of-print, doi: 10.1108/ECAM-10-2020-0848.

Giuniperio, L.C. and Dawn, H.P. (2000), "World-class purchasing skills: an empirical investigation", The Journal of Supply Chain Management, Vol. 36 No. 4, pp. 4-13.

Giunipero, L., Handfield, R.B. and Eltantawy, R. (2006), "Supply management's evolution: key skill sets for the supply manager of the future", International Journal of Operations \& Production Management, Vol. 26 No. 7, pp. 822-844.

Giunipero, L.C. and Pearcy, D.H. (2000), "World class purchasing skills: An empirical investigation", Journal of Supply Chain Management, Vol. 36 No. 4, pp. 4-13.

Grandia, J. (2016), "Finding the missing link: Examining the mediating role of sustainable public procurement behaviour", Journal of Cleaner Prodion, Vol. 124, pp. 183-190.

Grandia, J. and Meehan, J. (2017), "Public procurement as a policy tool: using procurement to reach desired outcomes in society", International Journal of Public Sector Management, Vol. 30 No. 4, pp. 302-309.

Grandia, J. and Voncken, D. (2019), "Sustainable public procurement: The impact of ability, motivation, and opportunity on the implementation of different types of sustainable public procurement", sustainability, Vol. 11, pp. 1-17.

Global Construction Perspectives and Oxford Economics, O. (2013), Global Construction 2025. A global forecast for the construction industry to 2025. Global Construction Perspectives and Oxford Economics.

Gunathilaka, S., Tuuli, M. M. and Dainty, A. R. J. (2013), "Critical analysis of research on project success in construction management journals", In: Smith, S.D and AhiagaDagbui, D.D (Eds) Proceedings of 29th Annual ARCOM Conference, Association of Researchers in Construction Management, Reading, UK,2-4 September.

Gurakar, E. C. and Tas, B. K. O. (2016), "Does public e-procurement deliver what it promises? Empirical evidence from Turkey", Emerging Markets Finance and Trade, Vol. 52 No. 11, pp. 2669-2684. 
Holtz, L. and Heitzig, C. (2021), Figures of the week: Africa's infrastructure paradox, available at: https://www.brookings.edu/blog/africa-in-focus/2021/02/24/figures-ofthe-week-africas-infrastructure-paradox/ (accessed 27/09/2021)

Humpherson, E. (2011), Necessary skills and the broader public sector capabilities for complex procurement. Available at: www.oecd.org/gov/budgeting/45038855.pdf, (accessed 3 July 2020).

Hwang, B.-G. and Ng, W.J. (2013), "Project management knowledge and skills for green construction: overcoming challenges", International Journal of Project Management, Vol. 31, pp. 272-284.

James, T. (2016), The rising importance of soft skills in procurement, available at: https://procurementandsupply.com/2016/02/the-rising-importance-of-soft-skills-inprocurement/, (accessed 28/09/2021)

Jordan, C. and Bak, O. (2016), "The growing scale and scope of the supply chain: A reflection on supply chain graduate skills", Supply Chain Management: An International Journal, Vol. 21 No. 5, pp. 610-626.

Kaduna State Government (2018), "Kaduna State Infrastructure Master Plan development plan 2018-2050". Kaduna: Kaduna State Government. Available online at http://kasupda.kdsg.gov.ng/wp-content/uploads/2018/07/KADIMP-Book email2.pdf (accessed 04/10/2021).

Kaufmann, L., Wagner, C.M. and Carter, C.R. (2017), "Individual modes and patterns of rational and intuitive decision-making by purchasing managers", Journal of Purchasing and Supply Management, Vol. 23 No.2, pp. 82-93.

Korteland, E. and Bekkers, V. (2008), "The diffusion of electronic service delivery innovations in Dutch E-policing: The case of digital warning systems", Public Management Review, Vol. 10 No. 1, pp. 71-88.

Kwofie, T.E., Amos-Abanyie, S. and Afram, S.O. (2016), "Principal component analysis of professional competencies of architects in the Ghanaian construction industry", Engineering, Construction and Architectural Management, Vol. 23 No. 5, pp. 571-587.

Lewinson, M. (2010), Key aspects in managing procurement team performance, available at: https://mymanagementguide.com/high-performance-purchasing-teamstaking-a-few-steps-to-achieve-better-procurement/ (accessed 29/09/2021)

Lewis, Y. R. \& Boucher, L. (2012), "PM-people management or project management?" Paper presented at PMI® Global Congress 2012-North America, Vancouver, British Columbia, Canada. Newtown Square, PA: Project Management Institute.

Love, P. E., Skitmore, M. and Earl, G. (1998), "Selecting a suitable procurement method for a building project", Construction Management and Economics, Vol. 16 No. 2, pp. 221-233.

Mahamadu, A-M., Manu, P., Booth, C., Olomolaiye, P., Coker, A., Ibrahim, A. and Lamond, J. (2018), "Infrastructure procurement skills gap amongst procurement 
personnel in Nigeria's public sector", Journal of Engineering, Design and Technology, Vol. 16 No. 1, pp. 2-24.

Manu, P., Mahamadu, A-M., Booth, C., Olomolaiye, P., Coker, A. Ibrahim, A. and Lamond, J. (2019), "Infrastructure procurement capacity gaps in Nigeria public sector institutions", Engineering, Construction and Architectural Management, Vol. 26 No. 9, pp. 1962-1985.

Manu, P., Mahamadu, A-M., Booth, C., Olomolaiye, P., Ibrahim, A. and Coker, A. (2018), "Assessment of procurement capacity challenges inhibiting public infrastructure procurement: A Nigerian inquiry", Built Environment Project and Asset Management, Vol. 8 No. 4, pp.386-402.

Nkado R.N. (2000), "Competencies required by quantity surveyors in South Africa", Proceedings of the 16th Annual ARCOM Conference, Association of Researchers in Construction Management, Glasgow Caledonian University, Glasgow, Sep 6-8, pp. $11-20$

OECD (2019) What does public procurement have to do with sustainability?

Available at: https://oecd-development-matters.org/2019/04/30/what-does-publicprocurement-have-to-do-with-sustainability/ (accessed 28/09/2021).

Ongaro, E. (2017), Public Procurement in Europe; Public Administration and Public Management in Europe; Palgrave MacMillan: London, UK, 2017; pp. 363-380.

Organisation for Economic Cooperation and Development (OECD) (2015), Towards a Framework for the Governance of Infrastructure, Public Governance and Territorial Development Directorate, OECD, Paris

Oke, A. E., Ogunsemi, D. R. and Adeyelu, M. F. (2018), "Quantity surveyors and skills required for procurement management", International Journal of Construction Management, Vol. 18 No. 6, pp. 507-516.

Oyo State Government (2010), Strategic health development plan (2010-2015).

Ibadan: Oyo State Government. Available online at

https://ngfrepository.org.ng:8443/jspui/bitstream/123456789/3207/1/Oyo\%20State\% 20Strategic\%20Health\%20Development\%20Plan\%202010-2015.doc.pdf (accessed 04/10/2021).

Parente, S. and Prescott, E. (2000), Barriers to Riches. Cambridge, MA: MIT Press.

Paulraj, A., Chen, I.J. and Flynn, J. (2006), "Levels of strategic purchasing: impact on supply integration and performance", Journal of Purchasing and Supply Management, Vol. 12 No. 3, pp. 107-122.

Preuss, L. (2009), "Addressing sustainable development through public procurement: the case of local government", Supply Chain Management: An International Journal, Vol. 14 No. 3, pp. 213-223.

Prier, E., McCue, C. and Behara, R. (2010), "The value of certification in public procurement: the birth of a profession?", Journal of Public Procurement, Vol. 10 No. 4, pp. 512-540. 
ProcureAbility (2020), Four important skills to look for when building a procurement team, available at: https://procureability.com/4-important-skills-to-look-for-whenbuilding-a-procurement-team/ (accessed 29/09/2021).

Rahmani, F., Maqsood, T. and Khalfan, M. (2017), "An overview of construction procurement methods in Australia", Engineering, Construction and Architectural Management, Vol. 24 No. 4, pp. 593-609.

Rimmington, M., Carlton Smith, J. and Hawkins, R. (2006), "Corporate social responsibility and sustainable food procurement", British Food Journal, Vol. 108 No. 10, pp. 824-837.

Saher, N. and Khan, S. (2018), "The impact of project planning on project success with moderating effect of project risk", International Conference on Contemporary Issues in Business \& Economics (ICCIBE), Tokat, Turkey, 14-15 July, pp. 317-331.

Schapper, P.R., Veiga Malta, J. and Gilbert, D.L. (2006), "An analytical framework for the management and reform of public procurement", Journal of Public Procurement, Vol. 6 Nos 1/2, pp. 1-26.

Shenhar, A.J. and Dvir, D. (2007), Reinventing Project Management: The Diamond Approach to Successful Growth and Innovation, Harvard Business School Press, Boston.

Shokri, S., Safa, M., Haas, C. T., Haas, R. C., Maloney, K. and MacGillivray, S. (2012), "Interface management model for mega capital projects: In Construction Research Congress 2012: Construction Challenges in a Flat World, pp. 447-456.

Tassabehji, R. and Moorhouse, A. (2008), "The changing role of procurement: developing professional effectiveness", Journal of Purchasing and Supply Management, Vol. 14 No. 1, pp. 55-68.

Tassabehji, R., Wallace, J. and Tsoularis, T. (2006), "Re-aligning reverse e-auctions for organisational agility", International Journal of Agile Systems and Management, Vol. 1 No. 4, pp. 346-359.

Thai, K. V. (2008). International handbook of public procurement. CRC Press.

Tremblay, P. and Boyle, A. (2018), Literature review on public procurement:

Theories, evidence and implications for regional Australia, available at:

https://www.cdu.edu.au/sites/default/files/the-northern-

institute/lit review on public procurement for regions.pdf, (accessed 27/09/2021)

United Nations Economic and Social Council (2016), Progress towards the Sustainable Development Goals - Report of the Secretary-General. United Nations Economic and Social Council. Available at: https://unstats.un.org/sdgs/files/report/2016/secretary-general-sdg-report-2016EN.pdf (accessed 23 March 2017).

United Nations Office for Project Services, UNOPS, (2010), Annual Statistical Report on the Procurement Activities of the United Nations System. Available at: 
https://content.unops.org/publications/ASR/ASR-

2010_EN.pdf?mtime=20171214185034, (accessed 27 August 2020)

Watermeyer, R. (2018), Client guide for improving infrastructure project outcomes, available

at:

https://cdn.ymaws.com/www.asaqs.co.za/resource/resmgr/downloads/Wits EAP Client guide.pdf, (accessed 27/09/2021).

Williams, A. M., Lau, F. and McCue, C. P. (2018), "Acknowledging knowledge: The perception of knowledge requirements for public procurement officials and their professional development", Journal of Public Procurement, Vol. 18 No. 1, pp. 50-67.

Witjes, S., and R. Lozano. (2016), "Towards a more circular economy: Proposing a framework linking sustainable public procurement and sustainable business models", Resources Conservation and Recycling, Vol. 112, pp. 37-44.

World Bank Group (2017), Africa's pulse: An analysis of issues shaping Africa's economic future, available at:

https://documents1.worldbank.org/curated/en/348741492463112162/pdf/114375REVISED-4-18-PMWB-AfricasPulse-Sping2017-vol15-ENGLISH-FINAL-web.pdf, (accessed 26/09/2021)

World Bank (2013), Nigeria Value Chain Analysis Study - A Study of Selected MDA's. World Bank Africa Report Number ACS 1666. Washington, DC: World Bank.

Yin, R.K. (2009), Case Study Research: Design and Methods, 4th ed. Sage Publications: Thousand Oaks, California.

Yasuyuki, S. (2015), The impacts of infrastructure in development: A selective survey, ADB Working Paper, No. 511, Asian Development Bank Institute (ADBI), Tokyo.

Zhao, Z.-Y., Zhao, X.-J., Zuo, J. and Zillante, G. (2016), "Corporate social responsibility for construction contractors: a China study", Journal of Engineering, Design and Technology, Vol. 14 No. 3, pp. 614-639. 
Table 1: Evolution in Procurement and Skills Requirements (adapted from Schapper et al. (2006))

\begin{tabular}{l|l|l}
\cline { 2 - 3 } & Traditional Procurement & Modern Procurement \\
\hline \multirow{4}{*}{ Characteristics } & Simple Processes & Complex Contracts and Relationships \\
& Large goods and products & Complete service solutions \\
& Low value, low risk & High value, high risk \\
& Back office function & Central to strategic management \\
& Warehousing & Just-in-time \\
\hline Skill requirements & Simple and Basic & Complex and multidisciplinary \\
\hline
\end{tabular}


Table 2: Procurement skills (adapted from Mahamadu et al., 2018)

\begin{tabular}{|c|c|}
\hline Skills & Example of sources \\
\hline Business case development & Carr and Smeltzer (2000), Giunipero et al. (2006), Tassabehji and Moorhouse (2008) \\
\hline Conflict resolution and management & Dainty et al. (2004), Tassabehji and Moorhouse (2008), Kwofie et al. (2016) \\
\hline Contract management and enforcement & Giunipero and Pearcy (2000), Tassabehji and Moorhouse (2008), Kwofie et al. (2016) \\
\hline Cost management and accounting compliance & Carr and Smeltzer (2000), Ahadzie et al. (2009), Addo-Duah et al. (2014) \\
\hline Creative thinking & Carr and Smeltzer (2000), Dainty et al. (2004), Tassabehji and Moorhouse (2008) \\
\hline Application of diversity and equal opportunities procedures & Mahamadu et al. (2018) \\
\hline Cross cultural awareness & Giunipero and Pearcy (2000), Moorhouse (2008) \\
\hline Data (quantitative and qualitative) analysis & $\begin{array}{l}\text { Giunipero and Pearcy (2000), Carr and Smeltzer (2000), Tassabehji and Moorhouse } \\
\text { (2008) }\end{array}$ \\
\hline Communication & Giunipero and Pearcy (2000), Tassabehji and Moorhouse (2008), Kwofie et al. (2016) \\
\hline Decision making & Dainty et al. (2004), Giunipero et al. (2006), Tassabehji and Moorhouse (2008) \\
\hline Entrepreneurship & Giunipero and Pearcy (2000), Mahamadu et al. (2018) \\
\hline Environmental management & Ahadzie et al. (2009), Mahamadu et al. (2018) \\
\hline Application of ethics guidelines in procurement & Mahamadu et al. (2018) \\
\hline E-procurement & Tassabehji and Moorhouse (2008), Mahamadu et al. (2018) \\
\hline Health and safety management & Ahadzie et al. (2009), Mahamadu et al. (2018) \\
\hline Leadership & Giunipero and Pearcy (2000), Giunipero et al. (2006), Addo-Duah et al. (2014) \\
\hline Market analysis and forecasting & Giunipero and Pearcy (2000), Tassabehji and Moorhouse (2008), Addo-Duah et al. (2014) \\
\hline Application of international procurement law and procedures & Mahamadu et al. (2018) \\
\hline Marketing & Mahamadu et al. (2018) \\
\hline Negotiation & Carr and Smeltzer (2000), Tassabehji and Moorhouse (2008), Kwofie et al. (2016) \\
\hline Computing/ICT & Carr and Smeltzer (2000), Giunipero et al. (2006), Addo-Duah et al. (2014) \\
\hline Problem solving & Carr and Smeltzer (2000), Tassabehji and Moorhouse (2008), Kwofie et al. (2016) \\
\hline Procurement planning & Tassabehji and Moorhouse (2008), Kwofie et al. (2016), Mahamadu et al. (2018) \\
\hline Project monitoring and auditing/evaluation & Carr and Smeltzer (2000), Addo-Duah et al. (2014), Kwofie et al. (2016) \\
\hline Project scope definition & Giunipero et al. (2006), Tassabehji and Moorhouse (2008), Addo-Duah et al. (2014) \\
\hline
\end{tabular}


Project strategy development/organisational governance

Proposal evaluation

Quality management

Application of corporate social responsibility procedures

Relationship management

Research and development

Responsible sourcing/Green purchasing/Green procurement

Risk management

Stakeholder management

Strategic planning

Application of modern integrated procurement procedures

Stress management

Sustainable design

Team building

Application of national procurement law and procedures

Tendering

Time management

Value engineering

Variation/Change management

Whole life costing and financial analysis
Giunipero et al. (2006), Tassabehji and Moorhouse (2008), Mahamadu et al. (2018)

Giunipero and Pearcy (2000), Giunipero et al. (2006), Addo-Duah et al. (2014)

Dainty et al. (2004), Tassabehji and Moorhouse (2008), Addo-Duah et al. (2014)

Mahamadu et al. (2018)

Giunipero and Pearcy (2000), Ahadzie et al. (2009), Addo-Duah et al. (2014)

Giunipero and Pearcy (2000), Giunipero et al. (2006), Kwofie et al. (2016)

Kwofie et al. (2016), Mahamadu et al. (2018)

Giunipero and Pearcy (2000), Tassabehji and Moorhouse (2008), Kwofie et al. (2016)

Tassabehji and Moorhouse (2008), Mahamadu et al. (2018)

Carr and Smeltzer (2000), Tassabehji and Moorhouse (2008), Addo-Duah et al. (2014)

Addo-Duah et al. (2014), Mahamadu et al. (2018)

Carr and Smeltzer (2000), Tassabehji and Moorhouse (2008)

Kwofie et al. (2016), Mahamadu et al. (2018)

Carr and Smeltzer (2000), Giunipero et al. (2006), Tassabehji and Moorhouse (2008)

Giunipero and Pearcy (2000), Addo-Duah et al. (2014), Kwofie et al. (2016)

Mahamadu et al. (2018)

Carr and Smeltzer (2000), Tassabehji and Moorhouse (2008), Ahadzie et al. (2009)

Ahadzie et al. (2009), Mahamadu et al. (2018)

Giunipero and Pearcy (2000), Tassabehji and Moorhouse (2008), Addo-Duah et al. (2014)

Dainty et al. (2004), Mahamadu et al. (2018) 
Table 3: Summary Questionnaire Response Rate

\begin{tabular}{c|c|c|c}
\hline Country & $\begin{array}{c}\text { Questionnaire } \\
\text { administered }\end{array}$ & $\begin{array}{c}\text { Useable questionnaire } \\
\text { received }\end{array}$ & Response rate \\
\hline Ghana & 480 & 302 & $62.92 \%$ \\
\hline Nigeria & 373 & 288 & $77.21 \%$ \\
\hline Total & 853 & 590 & $69.17 \%$ \\
\hline
\end{tabular}


Table 4: Background information for the survey participants

\begin{tabular}{|c|c|c|}
\hline \multirow{2}{*}{\multicolumn{3}{|c|}{ Frequency }} \\
\hline & & \\
\hline Procurement officer/personnel & 139 & 23.6 \\
\hline Engineer & 146 & 24.7 \\
\hline Quantity surveyor & 63 & 10.7 \\
\hline Purchasing officer/personnel & 35 & 5.9 \\
\hline Architect & 32 & 5.4 \\
\hline Land surveyor & 8 & 1.4 \\
\hline Administrator & 56 & 9.5 \\
\hline Urban/Town planner & 23 & 3.9 \\
\hline Estate surveyor & 25 & 4.2 \\
\hline Builder & 24 & 4.1 \\
\hline Other role & 39 & 6.6 \\
\hline \multicolumn{3}{|l|}{ Experience in role (years) } \\
\hline $0-5$ & 248 & 42.0 \\
\hline $6-10$ & 133 & 22.5 \\
\hline $11-15$ & 77 & 13.1 \\
\hline $16-20$ & 59 & 10.0 \\
\hline Over 20 & 46 & 7.8 \\
\hline Non-response & 27 & 4.6 \\
\hline Mean score $=9.12 ;$ Standard deviation $=7.29$ & & \\
\hline \multicolumn{3}{|l|}{ Experience in the procurement of infrastructure(years) } \\
\hline $0-5$ & 281 & 47.6 \\
\hline $6-10$ & 128 & 21.7 \\
\hline $11-15$ & 39 & 6.6 \\
\hline Over 15 & 40 & 6.8 \\
\hline Non-response & 102 & 17.3 \\
\hline Mean score $=6.62 ;$ Standard deviation $=5.70$ & & \\
\hline \multicolumn{3}{|l|}{ aType of infrastructure } \\
\hline Education & 151 & 25.6 \\
\hline Transport & 94 & 15.9 \\
\hline Power generation/Electricity & 86 & 14.6 \\
\hline Water and sanitation & 76 & 12.9 \\
\hline Health & 64 & 10.8 \\
\hline Housing & 189 & 32.0 \\
\hline \multicolumn{3}{|l|}{ aPhase of infrastructure procurement } \\
\hline Initiation/Planning stage & 195 & 33.1 \\
\hline Tendering/Sourcing stage & 238 & 40.3 \\
\hline Execution stage & 196 & 33.2 \\
\hline Closure and Review stage & 35 & 5.9 \\
\hline Disposal stage & 20 & 3.4 \\
\hline
\end{tabular}

Notes: aDue to multiple involvement in infrastructure type and procurement phase by some respondents, total percentage is greater than 100 . 
Table 5: One sample t-test for the importance of procurement skills for infrastructure procurement

\begin{tabular}{|c|c|c|c|c|c|c|c|c|c|c|c|c|}
\hline \multirow[b]{3}{*}{ Procurement skills } & \multirow[b]{3}{*}{$\mathrm{N}$} & \multirow[b]{3}{*}{ Mean } & \multirow{3}{*}{$\begin{array}{l}\text { Rank by } \\
\text { Mean }\end{array}$} & \multirow{3}{*}{$\begin{array}{c}\text { Std. } \\
\text { Deviation }\end{array}$} & \multirow{3}{*}{$\begin{array}{l}\text { Std. } \\
\text { Error } \\
\text { Mean }\end{array}$} & \multicolumn{7}{|c|}{ Test Value $=3.5$} \\
\hline & & & & & & \multirow[b]{2}{*}{$\mathrm{t}$} & \multirow[b]{2}{*}{$\mathrm{df}$} & \multirow{2}{*}{$\begin{array}{l}\text { Sig. }(2- \\
\text { tailed) }\end{array}$} & \multirow{2}{*}{$\begin{array}{l}\text { Sig. }(1- \\
\text { tailed) }\end{array}$} & \multirow{2}{*}{$\begin{array}{c}\text { Mean } \\
\text { Difference }\end{array}$} & \multicolumn{2}{|c|}{$\begin{array}{l}95 \% \text { Confidence } \\
\text { Interval of the } \\
\text { Difference } \\
\end{array}$} \\
\hline & & & & & & & & & & & Lower & Upper \\
\hline Communication (oral/written) & 590 & 4.329 & 1 & 0.857 & 0.035 & 23.501 & 589 & 0.000 & 0.000 & 0.829 & 0.76 & 0.90 \\
\hline Procurement planning & 588 & 4.241 & 2 & 1.889 & 0.078 & 9.520 & 587 & 0.000 & 0.000 & 0.741 & 0.59 & 0.89 \\
\hline Quality management & 590 & 4.190 & 3 & 0.806 & 0.033 & 20.786 & 589 & 0.000 & 0.000 & 0.690 & 0.62 & 0.76 \\
\hline $\begin{array}{l}\text { Project monitoring and } \\
\text { auditing/evaluation }\end{array}$ & 588 & 4.172 & 4 & 0.817 & 0.034 & 19.942 & 587 & 0.000 & 0.000 & 0.672 & 0.61 & 0.74 \\
\hline Time management & 589 & 4.166 & 5 & 0.808 & 0.033 & 20.021 & 588 & 0.000 & 0.000 & 0.666 & 0.60 & 0.73 \\
\hline Leadership & 587 & 4.162 & 6 & 0.796 & 0.033 & 20.136 & 586 & 0.000 & 0.000 & 0.662 & 0.60 & 0.73 \\
\hline $\begin{array}{l}\text { Value engineering } \\
\text { Health and safety }\end{array}$ & 589 & 4.146 & 7 & 0.861 & 0.035 & 18.219 & 588 & 0.000 & 0.000 & 0.646 & 0.58 & 0.72 \\
\hline management & 588 & 4.139 & 8 & 0.820 & 0.034 & 18.913 & 587 & 0.000 & 0.000 & 0.639 & 0.57 & 0.71 \\
\hline Tendering & 589 & 4.134 & 9 & 0.781 & 0.032 & 19.712 & 588 & 0.000 & 0.000 & 0.634 & 0.57 & 0.70 \\
\hline Decision making & 588 & 4.128 & 10 & 0.817 & 0.034 & 18.635 & 587 & 0.000 & 0.000 & 0.628 & 0.56 & 0.69 \\
\hline Computing/ICT & 588 & 4.126 & 11 & 0.845 & 0.035 & 17.969 & 587 & 0.000 & 0.000 & 0.626 & 0.56 & 0.69 \\
\hline Problem solving & 588 & 4.116 & 12 & 0.805 & 0.033 & 18.551 & 587 & 0.000 & 0.000 & 0.616 & 0.55 & 0.68 \\
\hline Team building & 589 & 4.102 & 13 & 0.751 & 0.031 & 19.442 & 588 & 0.000 & 0.000 & 0.602 & 0.54 & 0.66 \\
\hline Strategic planning & 589 & 4.100 & 14 & 0.852 & 0.035 & 17.091 & 588 & 0.000 & 0.000 & 0.600 & 0.53 & 0.67 \\
\hline Proposal evaluation & 587 & 4.094 & 15 & 0.826 & 0.034 & 17.413 & 586 & 0.000 & 0.000 & 0.594 & 0.53 & 0.66 \\
\hline $\begin{array}{l}\text { Relationship management } \\
\text { Application of national } \\
\text { procurement law and }\end{array}$ & 586 & 4.063 & 16 & 0.836 & 0.035 & 16.310 & 585 & 0.000 & 0.000 & 0.563 & 0.50 & 0.63 \\
\hline $\begin{array}{l}\text { procedures } \\
\text { Cost management and }\end{array}$ & 589 & 4.059 & 17 & 0.883 & 0.036 & 15.368 & 588 & 0.000 & 0.000 & 0.559 & 0.49 & 0.63 \\
\hline accounting compliance & 588 & 4.053 & 18 & 0.841 & 0.035 & 15.933 & 587 & 0.000 & 0.000 & 0.553 & 0.48 & 0.62 \\
\hline Negotiation & 588 & 4.049 & 19 & 0.873 & 0.036 & 15.255 & 587 & 0.000 & 0.000 & 0.549 & 0.48 & 0.62 \\
\hline Creative thinking & 585 & 4.041 & 20 & 0.881 & 0.036 & 14.857 & 584 & 0.000 & 0.000 & 0.541 & 0.47 & 0.61 \\
\hline
\end{tabular}


Application of ethics guidelines in procurement

Contract management and enforcement

Data (quantitative and

qualitative) analysis

Environmental management

Project strategy

development/organisational

governance

Sustainable design

Project scope definition

Application of modern

integrated procurement

procedures

Variation/Change

management

Market analysis and

forecasting

Stakeholder management

Risk management

Conflict resolution and

management

Whole life costing and

financial analysis

Application of diversity and

equal opportunities

procedures

Application of international procurement law and

procedures

Research and development

E-procurement

\begin{tabular}{|c|c|c|c|c|c|c|c|c|c|c|c|}
\hline 587 & 4.041 & 21 & 0.937 & 0.039 & 13.979 & 586 & 0.000 & 0.000 & 0.541 & 0.46 & 0.62 \\
\hline 587 & 4.027 & 22 & 0.846 & 0.035 & 15.097 & 586 & 0.000 & 0.000 & 0.527 & 0.46 & 0.60 \\
\hline 589 & 4.020 & 23 & 0.799 & 0.033 & 15.798 & 588 & 0.000 & 0.000 & 0.520 & 0.46 & 0.59 \\
\hline 590 & 3.993 & 24 & 0.856 & 0.035 & 13.989 & 589 & 0.000 & 0.000 & 0.493 & 0.42 & 0.56 \\
\hline 586 & 3.993 & 25 & 0.812 & 0.034 & 14.698 & 585 & 0.000 & 0.000 & 0.493 & 0.43 & 0.56 \\
\hline 587 & 3.983 & 26 & 0.860 & 0.036 & 13.600 & 586 & 0.000 & 0.000 & 0.483 & 0.41 & 0.55 \\
\hline 585 & 3.979 & 27 & 0.821 & 0.034 & 14.124 & 584 & 0.000 & 0.000 & 0.479 & 0.41 & 0.55 \\
\hline 588 & 3.974 & 28 & 0.893 & 0.037 & 12.877 & 587 & 0.000 & 0.000 & 0.474 & 0.40 & 0.55 \\
\hline 586 & 3.969 & 29 & 0.835 & 0.034 & 13.612 & 585 & 0.000 & 0.000 & 0.469 & 0.40 & 0.54 \\
\hline 588 & 3.963 & 30 & 0.831 & 0.034 & 13.501 & 587 & 0.000 & 0.000 & 0.463 & 0.40 & 0.53 \\
\hline 588 & 3.952 & 31 & 0.899 & 0.037 & 12.199 & 587 & 0.000 & 0.000 & 0.452 & 0.38 & 0.53 \\
\hline 587 & 3.922 & 32 & 0.951 & 0.039 & 10.738 & 586 & 0.000 & 0.000 & 0.422 & 0.34 & 0.50 \\
\hline 588 & 3.920 & 33 & 0.919 & 0.038 & 11.090 & 587 & 0.000 & 0.000 & 0.420 & 0.35 & 0.49 \\
\hline 587 & 3.913 & 34 & 0.857 & 0.035 & 11.677 & 586 & 0.000 & 0.000 & 0.413 & 0.34 & 0.48 \\
\hline 585 & 3.908 & 35 & 0.875 & 0.036 & 11.271 & 584 & 0.000 & 0.000 & 0.408 & 0.34 & 0.48 \\
\hline 589 & 3.905 & 36 & 0.936 & 0.039 & 10.504 & 588 & 0.000 & 0.000 & 0.405 & 0.33 & 0.48 \\
\hline 589 & 3.903 & 37 & 0.878 & 0.036 & 11.143 & 588 & 0.000 & 0.000 & 0.403 & 0.33 & 0.47 \\
\hline 588 & 3.869 & 38 & 0.949 & 0.039 & 9.427 & 587 & 0.000 & 0.000 & 0.369 & 0.29 & 0.45 \\
\hline
\end{tabular}




\begin{tabular}{|c|c|c|c|c|c|c|c|c|c|c|c|c|}
\hline $\begin{array}{l}\text { Responsible sourcing/Green } \\
\text { purchasing/Green } \\
\text { procurement }\end{array}$ & 588 & 3.838 & 39 & 0.962 & 0.040 & 8.528 & 587 & 0.000 & 0.000 & 0.338 & 0.26 & 0.42 \\
\hline Marketing & 586 & 3.834 & 40 & 0.852 & 0.035 & 9.500 & 585 & 0.000 & 0.000 & 0.334 & 0.27 & 0.40 \\
\hline $\begin{array}{l}\text { Entrepreneurship } \\
\text { Application of corporate } \\
\text { social responsibility } \\
\text { procedures }\end{array}$ & 587 & 3.816 & 41 & 0.940 & 0.039 & 8.142 & 586 & 0.000 & 0.000 & 0.316 & 0.24 & 0.39 \\
\hline Business case development & 586 & 3.797 & 43 & 0.882 & 0.036 & 8.152 & 585 & 0.000 & 0.000 & 0.297 & 0.23 & 0.37 \\
\hline Stress management & 587 & 3.775 & 44 & 0.931 & 0.038 & 7.157 & 586 & 0.000 & 0.000 & 0.275 & 0.20 & 0.35 \\
\hline Cross cultural awareness & 587 & 3.702 & 45 & 0.932 & 0.038 & 5.249 & 586 & 0.000 & 0.000 & 0.202 & 0.13 & 0.28 \\
\hline
\end{tabular}

Notes: Scale: 1 = strongly disagree; 2 = disagree; $3=$ neutral; $4=$ agree; $5=$ strongly agree 
Table 6: Exploratory factor analysis results

\begin{tabular}{|c|c|c|c|c|c|c|c|c|c|}
\hline \multirow[t]{2}{*}{ Infrastructure Procurement Skills } & \multirow{2}{*}{$\begin{array}{c}\text { Communalities after } \\
\text { extraction }\end{array}$} & \multicolumn{8}{|c|}{ Components of Important Infrastructure Procurement Skills } \\
\hline & & 1 & 2 & 3 & 4 & 5 & 6 & 7 & 8 \\
\hline Strategic planning & 0.564 & 0.660 & & & & & & & \\
\hline Quality management & 0.546 & 0.628 & & & & & & & \\
\hline Responsible sourcing/Green purchasing/Green procurement & 0.615 & 0.612 & & & & & & & \\
\hline Risk management & 0.536 & 0.604 & & & & & & & \\
\hline Relationship management & 0.525 & 0.597 & & & & & & & \\
\hline Time management & 0.424 & 0.534 & & & & & & & \\
\hline Proposal evaluation & 0.492 & 0.531 & & & & & & & \\
\hline Cross cultural awareness & 0.695 & & 0.734 & & & & & & \\
\hline Stress management & 0.639 & & 0.729 & & & & & & \\
\hline Application of corporate social responsibility procedures & 0.639 & & 0.659 & & & & & & \\
\hline Environmental management & 0.629 & & 0.642 & & & & & & \\
\hline Health and safety management & 0.617 & & 0.587 & & & & & & \\
\hline Marketing & 0.558 & & & 0.669 & & & & & \\
\hline E-procurement & 0.575 & & & 0.619 & & & & & \\
\hline Research and development & 0.524 & & & 0.565 & & & & & \\
\hline Sustainable design & 0.610 & & & 0.550 & & & & & \\
\hline Tendering & 0.628 & & & & 0.722 & & & & \\
\hline Project monitoring and auditing/evaluation & 0.587 & & & & 0.630 & & & & \\
\hline Project scope definition & 0.574 & & & & 0.600 & & & & \\
\hline Project strategy development/organizational governance & 0.572 & & & & 0.599 & & & & \\
\hline Application of international procurement law and procedures & 0.713 & & & & & 0.785 & & & \\
\hline Application of national procurement law and procedures & 0.696 & & & & & 0.744 & & & \\
\hline Application of modern integrated procurement procedures & 0.630 & & & & & 0.698 & & & \\
\hline
\end{tabular}


Creative thinking

Problem solving

Entrepreneurship

Decision making

Computing/ICT

Communication (oral/written)

Conflict resolution and management

Data (quantitative and qualitative) analysis

Team building

\begin{tabular}{|c|c|c|c|c|c|c|c|c|}
\hline 0.655 & & & & & & 0.661 & & \\
\hline 0.649 & & & & & & 0.616 & & \\
\hline 0.580 & & & & & & 0.574 & & \\
\hline 0.531 & & & & & & 0.554 & & \\
\hline 0.634 & & & & & & & 0.744 & \\
\hline 0.625 & & & & & & & 0.698 & \\
\hline 0.539 & & & & & & & 0.606 & \\
\hline 0.582 & & & & & & & & 0.589 \\
\hline 0.546 & & & & & & & & 0.553 \\
\hline Eigen value & 14.284 & 2.294 & 1.779 & 1.524 & 1.250 & 1.233 & 1.132 & 1.054 \\
\hline Variance explained & 32.464 & 5.213 & 4.044 & 3.464 & 2.841 & 2.802 & 2.573 & 2.396 \\
\hline Scale's Cronbach alpha & 0.832 & 0.837 & 0.749 & 0.759 & 0.797 & 0.748 & 0.705 & 0.649 \\
\hline
\end{tabular}

Notes: The Method of Extraction: Principal Component Analysis. Method of Rotation: Varimax

Kaiser-Meyer-Olkin Measure of Sampling Adequacy $=0.946$.

Variance explained by 8 factors $=55.796 \%$.

Bartlett's Test of Sphericity: Chi-Square $=10754.381(\mathrm{df}=946), p<0.001$.

Factor loadings below 0.5 have been suppressed. 